\title{
Implementation of HACCP Plan for the Production of Egyptian Kishk (A Traditional Fermented Cereal-Milk Mixture)
}

\author{
Mohamed M. Abd El-Razik,2, Mohamed F. Y. Hassan²,3, Mohamed G. E. Gadallah ${ }^{1,2}$ \\ ${ }^{1}$ Department of Food Science, Faculty of Agriculture, Ain Shams University, Cairo, Egypt \\ ${ }^{2}$ Department of Food Science \& Human Nutrition, Faculty of Agriculture and Veterinary Medicine, Qassim University, Buraydah, KSA \\ ${ }^{3}$ Department of Dairy Science, Faculty of Agriculture, Sohag University, Sohag, Egypt \\ Email: mabdelrazik1969@yahoo.com
}

How to cite this paper: Abd El-Razik, M.M., Hassan, M.F.Y. and Gadallah, M.G.E. (2016) Implementation of HACCP Plan for the Production of Egyptian Kishk (A Traditional Fermented Cereal-Milk Mixture). Food and Nutrition Sciences, 7, 1262-1275. http://dx.doi.org/10.4236/fns.2016.713116

Received: October 15, 2016

Accepted: November 12, 2016

Published: November 15, 2016

Copyright $\odot 2016$ by authors and Scientific Research Publishing Inc. This work is licensed under the Creative Commons Attribution International License (CC BY 4.0).

http://creativecommons.org/licenses/by/4.0/ (c) (i) Open Access

\begin{abstract}
The aim of this study is implementation of Hazard Analysis and Critical Control Points (HACCP) system during production of Egyptian Kishk on small scale production. Kishk is a traditional dry fermented product consisted from salted sour butter milk (Laban zeer) or yoghurt with cracked and bran free parboiled wheat grains (Burghol); the mixture of cereal and milk allows fermenting at ambient temperature for different periods, then the fermented mixture is formed in ball form and dried. Kishk is consumed in Egypt and in most Arab countries. Since Kishk is prepared by traditional and consumed widely, safety of this product is very important in terms of consumer health. Therefore, HACCP system as food safety tool was adopted during preparation of Kishk. Hazard analysis of raw materials and during different production steps was established. A simple HACCP plan was implemented; critical control points of production were determined; critical limits, corrective actions and monitoring procedures for each critical control points were established; verification procedures were also discussed.
\end{abstract}

\section{Keywords}

HACCP, Kishk, Safety, Verification

\section{Introduction}

According to National Advisory Committee on Microbiological Criteria for Foods [1], HACCP is a management system in which food safety is addressed through the analysis and control of biological, chemical and physical hazards from raw material production, 
procurement and handling to manufacturing, distribution and consumption of the finished product. HACCP is a technique used to analyze potential hazards in an operation, identifying where these may occur and how much these are critical to consumer safety. It also establishes control systems that focus on the prevention of such hazards rather than relying on end-product testing [2]. HACCP system has become synonymous with food safety. It is a worldwide recognized systematic and preventive approach that addresses biological, chemical and physical hazards through anticipation and prevention rather than through inspection and testing of end-product, [3]. HACCP system is a systematic approach to the identification, assessment of risk and control of the biological, chemical and physical hazards associated with each part of the food system from production to consumption, following the seven basic principles: 1) Identification of hazards that may be present from harvest through ultimate consumption and preventive measures for controlling them, 2) Determination of Critical Control Points (CCPs) required to control the identified hazards, 3) Establishment of critical limits that must be met at each CCP, 4) Establish appropriate monitoring procedures for each identified CCPs, 5) Establishment of corrective actions that should be taken when CCPs are not under control, 6) Establishment of procedures for verification that HACCP system is working according to the plan and 7) Documentation records concerning all procedures and records appropriate to principles 1 through 6, National Advisory Committee on Microbiological Criteria for Foods [1]. In general, HACCP aims to eliminate influences that result in food borne diseases in humans from the production, handling, treatment, transportation and storage of foods.

Kishk is one of the traditional fermented food products in Egypt. It is a mixture of fermented milk with wheat grains and stored in the form of dried balls. Kishk is a balanced food with excellent storage stability, [4]. Kishk and related products made in the region between the eastern Mediterranean and the Indian sub-continent are manufactured using low-fat yoghurt (or buttermilk from churned fermented milk), parboiled cracked wheat (known locally as Burghol) and salt. The cultured milk may be made from bovine, caprine, ovine milk or from mixed milk [5] [6] [7].

Differences in the preparation methods of Kishk and the cereal used can affect the composition, nutritional properties and microbiological characteristics of the final product [8]. The microbiological characteristics of Kishk are affected by many factors e.g. the microbiological load of grains, the fermentation method, the drying method and the sanitary conditions of processing stages of the Kishk. The low moisture content $(<10 \%)$, natural acidic of Kishk ( $\mathrm{pH} 3.8$ ) and addition of salt during preparation $(2.8 \%$ $\mathrm{NaCl}$ in the dried product) may suggest the microbiological safety of Kishk, [9]. According to [10], in only one of eight Egyptian Kishk samples tested faecal enterococci was found at count of $3.4 \times 10^{2} \mathrm{cfu} / \mathrm{g}$. At the same time, the undesirable microbial groups were found in tested commercial Egyptian Kishk by [8] which were mainly spore forming bacteria i.e. Bacillus spp., yeast and molds. The controlling of hygiene applied during production of Kishk and the quality of raw materials used, mainly the Burghol, and it indicates that with improved hygiene, the microbiological quality of the 
Kishk could be improved, [11]. Where Kishk produced by traditional methods is consumed widely in Egypt and take an important role in diets of many people, so safety of Kishk is very important for consumer health. Therefore, applying HACCP system as a food safety tool during production of Kishk is very important. So the aim of this investigation is implementation HACCP system during production of Kishk on small scale production. Hazard analysis of raw materials and during different production steps was established. A simple HACCP plan was planned, critical control points of production were determined, critical limits, corrective actions and monitoring procedures for each critical control points were established, verification procedures were also discussed.

\section{Materials and Methods}

\subsection{Materials}

Four types of cereals e.g. Local and imported wheat (Triticum astevium) grains were kindly obtained from Saudi Grains Organization (SAGO), Buraidah, Qassim region during the summer of 2015. Barley (Hordeum valgare) grains and pearl millet (Pennisetum glaucum) grains were purchased from the local market, Buraidah, Qassim region. Cow milk and goat milk used in yoghurts preparation were obtained from the Agriculture and Veterinary Research and Experiments Center followed Qassim University. Starter cultures were obtained from Christian Hansen (Copenhagen, Denmark) was Yo-flex culture (Yc-183), which is a mixed strain culture of Streptococcus thermophilus and Lactobacillus delbrueckii subsp. Bulgaricus at a ratio 1:1. The reagents used for the chemical analyses were of analytical grade.

\subsection{Methods}

\subsubsection{Preparation of Kishk}

Different Kishk samples were prepared from cow or goat milk with imported local wheat, barley or millet grains and the abbreviation codes of Kishk samples are listed in Table 1. The different processing steps of yoghurt according to method described by Tamime and Robisons (2007) [12] were illustrated by Figure 1 and processing steps of

Table 1. Abbreviation codes of prepared different Kishk samples.

\begin{tabular}{cc}
\hline Kishk code & Raw materials used in Kishk preparation \\
\hline CW1 & Cow yoghurt with imported wheat grains \\
CW2 & Cow yoghurt with local wheat grains \\
CB & Cow yoghurt with barley grains \\
CM & Cow yoghurt with millet grains \\
GW1 & Goat yoghurt with imported wheat grains \\
GW2 & Goat yoghurt with local wheat grains \\
GB & Goat yoghurt with barley grains \\
GM & Goat yoghurt with millet grains \\
\hline
\end{tabular}

${ }^{*}$ grain: yoghurt ratio is 1:4. 
Receiving of raw cow and goat milk samples.

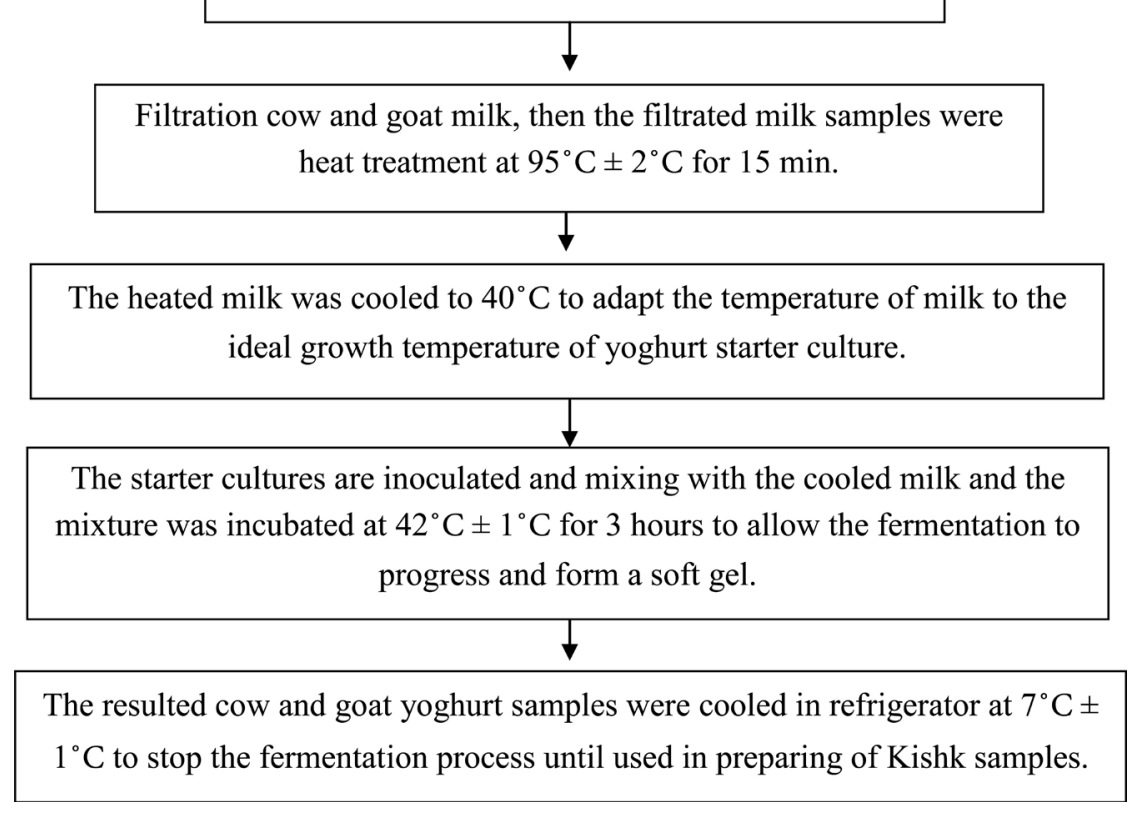

Figure 1. Flow diagram of preparation steps of cow and goat yoghurt samples.

Kishk samples were illustrated by Figure 2 according to method described by Tamime, et al. (1997) [13]. Different prepared Kishk samples were analyzed after preparation.

\subsubsection{Water Activity, Acidity and pH Value of Kishk}

Water activity of Kishk samples was determined using AQUA LAB (model series 3), USA by methods described by Landrock and Proctor (1951) [14]. Samples (in small plastic cups) were equilibrated against the saturated salt solution at $20^{\circ} \mathrm{C}$. The prepared Kishk samples were analyzed for their titratable acidity (calculated as \% of lactic acid) as reported by Ling (1963) [15]. The $\mathrm{pH}$ of the prepared Kishk samples were measured according to the method of Adeleke and Odedeji (2010) [16] using a $\mathrm{pH}$ meter (HANNA, HI 9025) already standardized with buffer solutions of $\mathrm{pH} 4.0$ and 7.0.

\subsubsection{Microbiological Analysis}

Different prepared Kishk samples were microbiologically analyzed after preparation. Different Kishk samples (10 g from each) were aseptically taken, homogenized in $90 \mathrm{ml}$ of sterile diluent ( $0.1 \%$ peptone water) with a Stomacher (Seward, Model 400, England) for $30 \mathrm{sec}$., serial dilutions were prepared in peptone water, IDF (1992) [17].

Kishk samples were examined for total viable bacterial counts, ADPI (1990) [18], lactic acid bacteria, IDF (1991) [19], yeasts and molds, IDF (1990) [20] and coliforms, IDF (1985) [21]. After incubation, the colonies (30 - 300 colonies) developed on agar plates were counted. Each value represents the mean of duplicate and results were expressed as Log Colony Forming units per gram (log CFU/g), AOAC (2005) [22].

\subsubsection{Application of HACCP System}

According to the (NACMCF, 1998) [1] and (NACMCF, 1992) [23], HACCP system was 


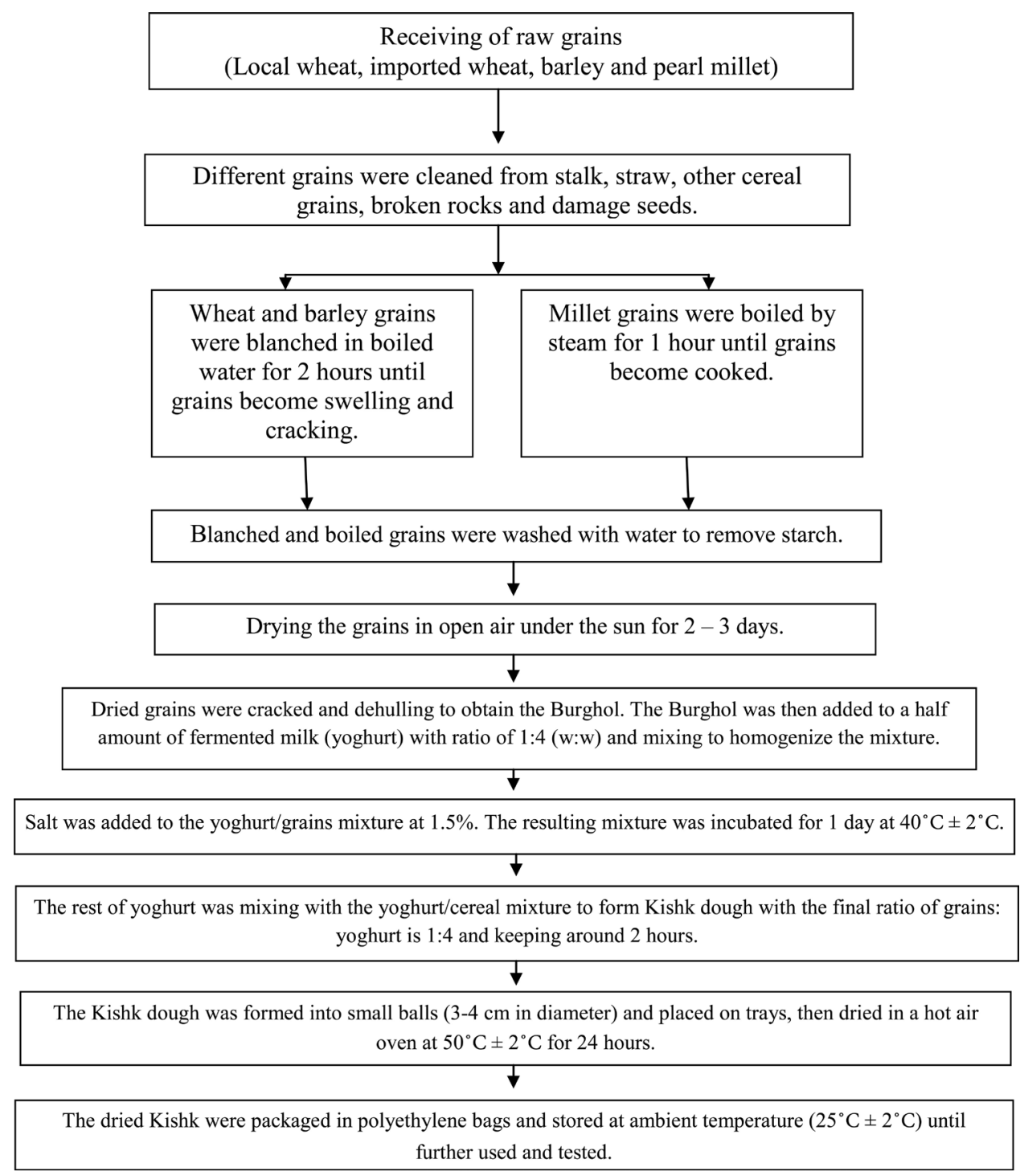

Figure 2. Flow diagram of preparation steps of Kishk samples.

implemented during different preparation steps of Kishk samples based on the following seven principles: 1) Conduct a hazard analyses; 2) Identify the critical control points (CCPs); 3) Establish critical limits for preventive measures associated with each identified CCP; 4) Establish CCP monitoring requirements; 5) Establish corrective actions to be taken when monitoring indicates then a deviation from an established critical limit; 6) Establish verification procedures and 7) Establish record-keeping and documentation procedures. The results were summarized with reference to CCPs and their monitoring on the HACCP worksheet.

\subsubsection{Statistical Analysis}

Water activity, acidity and $\mathrm{pH}$ of Kishk were expressed as the means \pm SE. Statistical analysis was carried out using the PROC ANOVA followed by Duncan's Multiple Range Test with $\mathrm{p} \leq 0.05$ being considered statistically significant to compare between 
means according to Snedecor and Cochran (1980) [24]. All procedures were triplicate using Statistical Analysis System program, SAS (2000) [25].

\section{Results and Discussion}

\subsection{Description of the Product}

Egyptian Kishk is a mixture of fermented milk and wheat. It is a dry fermented food made from Laben zeer (salted sour buttermilk) or yoghurt with bulgur (cracked and bran-free parboiled wheat) and allows the mixture to ferment at ambient temperature for different periods. Kishk consumed in Egypt and in most Arab countries [26]. pH, acidity and water activity of different prepared Kishk samples were determined and the obtained results are presented in Table 2. It could be noticed that, $\mathrm{pH}$ values of different prepared Kishk samples ranged from 4.39 to 4.84 , where values of acidity as \% lactic acid and water activity were ranged from $1.27 \%$ to $1.50 \%$ and 0.31 to 0.35 , respectively. These results may in meet the findings of [27] and [28]. Acidification and low water activity of Kishk extended the shelf-life and improved the safety of product.

\subsection{Hazard Analysis of Raw Materials and Preparation Steps of Kishk}

Each ingredient used in preparation of different Kishk samples and preparing steps were analyzed with taken into consideration individually in terms of HACCP system. Possible biological, chemical and physical hazards of Kishk ingredients and preparation steps were identified and listed in Table 3, at the same time, control measures of each identified hazard were determined. As reported in Table 3, different biological, chemical and physical hazards were analyzed during receiving wheat, barley, millet, yoghurt and salt. Hazards could be listed as pathogenic bacteria, spore forming bacteria and yeast and mold, (biological), since different aforementioned grains is dry foodstuff, the most important microbiological hazards were spore forming bacteria and presence of yeast and mold as presence of them could resulted presence of Mycotoxins. Therefore,

Table 2. pH, acidity (\% as lactic acid) and water activity of prepared Kishk from different cereals and milk sources.

\begin{tabular}{cccc}
\hline Kishk samples & pH & Acidity & Water activity \\
\hline CW1 & $4.81 \pm 0.01^{\mathrm{b}}$ & $1.32 \pm 0.04^{\mathrm{d}}$ & $0.34 \pm 0.08^{\mathrm{ab}}$ \\
CW2 & $4.84 \pm 0.01^{\mathrm{a}}$ & $1.27 \pm 0.02^{\mathrm{e}}$ & $0.31 \pm 0.02^{\mathrm{d}}$ \\
CB & $4.63 \pm 0.16^{\mathrm{d}}$ & $1.38 \pm 0.01^{\mathrm{b}}$ & $0.34 \pm 0.01^{\mathrm{ab}}$ \\
CM & $4.39 \pm 0.08^{\mathrm{f}}$ & $1.50 \pm 0.03^{\mathrm{a}}$ & $0.33 \pm 0.05^{\mathrm{bc}}$ \\
GW1 & $4.82 \pm 0.17^{\mathrm{ab}}$ & $1.29 \pm 0.04^{\mathrm{e}}$ & $0.32 \pm 0.08^{\mathrm{c}}$ \\
GW2 & $4.84 \pm 0.20^{\mathrm{a}}$ & $1.27 \pm 0.02^{\mathrm{e}}$ & $0.31 \pm 0.04^{\mathrm{d}}$ \\
GB & $4.69 \pm 0.18^{\mathrm{c}}$ & $1.35 \pm 0.11^{\mathrm{c}}$ & $0.35 \pm 0.07^{\mathrm{a}}$ \\
GM & $4.42 \pm 0.04^{\mathrm{e}}$ & $1.48 \pm 0.03^{\mathrm{a}}$ & $0.35 \pm 0.05^{\mathrm{a}}$ \\
\hline
\end{tabular}

Data are the mean $\pm S E, n=3$, Means having the same letter within each property are not significant difference at ( $p$ $\geq 0.05)$. 
Table 3. Hazard Analysis of raw materials and different preparation steps of Kishk samples.

\begin{tabular}{|c|c|c|c|c|}
\hline Preparation step & \multicolumn{3}{|c|}{ Hazard } & Control measures \\
\hline Cleaning of grains. & Non & Non & $\begin{array}{l}\text { Different impurities } \\
\text { and foreign materials. }\end{array}$ & $\begin{array}{l}\text { Maintains of sieves, sanitation standard } \\
\text { operating procedures and good manufacturing } \\
\text { practices. }\end{array}$ \\
\hline $\begin{array}{l}\text { Blanching of wheat and } \\
\text { barley grains. }\end{array}$ & Non & Non & Non & Non \\
\hline \multicolumn{5}{|l|}{ Steam boiled of millet grains. } \\
\hline $\begin{array}{l}\text { Cracked and dehulling of } \\
\text { dried grains. }\end{array}$ & Non & Non & $\begin{array}{l}\text { Different impurities } \\
\text { and foreign materials. }\end{array}$ & $\begin{array}{l}\text { Maintains of sieves and good manufacturing } \\
\text { practices. }\end{array}$ \\
\hline $\begin{array}{l}\text { Mixing of burghol with } \\
\text { yoghurt and salt. }\end{array}$ & $\begin{array}{l}\text { Pathogenic bacteria, } \\
\text { spore forming bacteria } \\
\text { and yeast and mold. }\end{array}$ & Non & Foreign materials. & $\begin{array}{l}\text { Sanitation standard operating procedures, good } \\
\text { manufacturing practices, acidity of yoghurt and } \\
\text { concentration of salt. }\end{array}$ \\
\hline Incubation of the mixture. & $\begin{array}{l}\text { Pathogenic bacteria, } \\
\text { spore forming bacteria } \\
\text { and yeast and mold. }\end{array}$ & Non & Non & $\begin{array}{l}\text { Sanitation standard operating procedures, good } \\
\text { manufacturing practices, acidity, } \mathrm{pH} \text { and } \\
\text { concentration of salt in the mixing. }\end{array}$ \\
\hline Kishk packaging and stored. & Non & Non & Non & Non \\
\hline
\end{tabular}

Mycotoxins, pesticides residues, heavy metals and different impurities, foreign materials were identified as chemical and physical hazards, respectively. Control measures could be used in controlling the aforementioned hazards could be identified as certified suppliers of raw ingredients complains with raw materials specifications and good manufacturing practices (GMPs). So, the receipt of raw ingredients used in Kishk preparation is in accordance with the standards and requirements of the particular source of regulations and circulars issued by the Ministry of Municipal and Rural Affairs, www.momra.gov.sa, Saudi Food \& Drug Authority and www.sfda.gov.sa. At the same time, microbiological, chemical and physical characteristics of ingredients used in preparing Kishk samples should be under the upper limits given in Guides of microbiological specifications and criteria for foods \& harmful residues in food. As found in Figure 1, different preparation steps of Kishk samples were illustrated and the hazard 
analysis results of these steps were reported in Table 3 with listed any control measures could be used in prevent, eliminate and reduce each identified hazard to an acceptable level. Cleaned grains are an important preparation step in preparing Kishk for removal of different impurities and foreign materials found in different grains. The control measures of this step were maintains of sieves, sanitation standard operating procedures (SSOPs) and (GMPs). Cracked and dehulling of dried grains step is important as the aforementioned step since this step is performed for removing different physical hazards could be found after drying process, at the same time, the control measures listed in cleaned grains step could be used in cracked and dehulling step. During preparation Kishk incubation step of burghol/yoghurt mixed and step of Kishk formed and dried are performed for controlling different biological hazards (pathogenic bacteria, spore forming bacteria and yeast and mold) from raw ingredients and during different preparation steps. SSOPs, GMPs, acidity, $\mathrm{pH}$, salt concentration and water activity of Kishk could be used as control measures for controlling the identified biological hazards (Table 3).

\subsection{Critical Control Points during Preparation Steps of Kishk}

Critical control points (CCPs) are processing step where control measures could be performed to prevent, eliminate and reduce any identified hazards (biological, chemical and physical) to an acceptable level, [29]. A decision tree was used for identified preparation step could be established as CCP during preparation Kishk and the results were shown in Table 4. It could be noticed that, receiving raw ingredients of preparation Kishk samples is the first identified CCP, as listed in Table 3, three types of hazards biological, chemical and physical were identified so this step could be used as CCP for controlling the identified hazards listed in Table 3. The other identified CCPs during preparation Kishk were cleaned grains; incubation period of burghol/yoghurt mixed and dried Kishk for controlling physical and biological hazards, respectively.

\subsection{Critical Limits}

Critical limits of each identified CCP during preparation Kishk were determined. The critical limits of receiving raw ingredients should be listed in supplier guarantee specifications of each ingredients established by Ministry of Municipal and Rural Affairs, www.momra.gov.sa and Saudi Food \& Drug Authority, www.sfda.gov.sa. So levels of different hazards in raw ingredients should be under the maximum values listed in guides of microbiological specifications and criteria for foods \& harmful residues in food (www.momra.gov.sa). At the same time, microbiological, chemical and visual inspections of all raw materials should be taken into consideration according to established HACCP plan. Sieved grains should not contain physical hazards was the critical limit of cleaning grains step. The conditions of incubation and drying steps as temperature \& time were established as critical limits for incubation and drying steps during preparing Kishk product. Temperature and time of incubation were $40^{\circ} \mathrm{C} \pm 2^{\circ} \mathrm{C}$ and $24 \mathrm{hr}$, respectively, where their values were $50^{\circ} \mathrm{C} \pm 2^{\circ} \mathrm{C}$ and $24 \mathrm{hr}$, respectively for drying step. 
Table 4. Critical control points (CCPs) during the manufacture of Kishk samples.

\begin{tabular}{|c|c|c|c|c|c|c|}
\hline \multirow[t]{2}{*}{ Preparation step } & \multicolumn{4}{|c|}{$\begin{array}{l}\text { Decision tree } \\
\text { questions }^{*}\end{array}$} & \multirow[t]{2}{*}{$\mathrm{CCP}$} & \multirow[t]{2}{*}{ Hazard } \\
\hline & Q1 & Q2 & Q3 & Q4 & & \\
\hline $\begin{array}{l}\text { Receiving wheat, barley and millet grains } \\
\text { and cow or goat yoghurt and salt. }\end{array}$ & Yes & Yes & - & - & $\mathrm{CCP}$ & Biological, chemical and physical. \\
\hline Cleaning of grains. & Yes & Yes & - & - & CCP & Physical \\
\hline Blanching of wheat and barley grains. & Yes & No & No & - & - & - \\
\hline Steam boiled of millet grains. & Yes & No & No & - & - & - \\
\hline Remove of starch from grains. & Yes & No & No & - & - & - \\
\hline Drying of grains. & Yes & No & No & - & - & - \\
\hline Cracked and dehulling of dried grains. & Yes & No & No & - & - & - \\
\hline Mixing of burghol with yoghurt and salt. & Yes & No & No & - & - & - \\
\hline Incubation of mixture. & Yes & Yes & - & - & $\mathrm{CCP}$ & Biological \\
\hline Mixing the mixture with rest of yoghurt. & Yes & No & No & - & - & - \\
\hline Kishk formed and dried. & Yes & Yes & - & - & $\mathrm{CCP}$ & Biological \\
\hline Kishk packaging and stored. & Yes & No & No & - & - & - \\
\hline
\end{tabular}

*: NACMCF (1998).

Q1: Do preventative control measures exist?

Q2: Is the step specifically designed to eliminate or reduce the likely occurrence of a hazard to an acceptable level?

Q3: Could contamination with identified hazard(s) occur in excess of acceptable levels?

Q4: Will subsequent step(s) eliminate or reduce the hazard to an acceptable level?

\subsection{Monitoring Procedures}

Visual inspection of supplier guarantee for each ingredient and cleaned grains could be established as monitoring procedures for CCPs of receiving raw ingredients and cleaning grains, respectively. Where checking temperature and time of incubation and drying steps (third and fourth CCP during Kishk preparing) could be used as monitoring procedures for these CCPs. At the same time, measuring $\mathrm{pH}$, acidity and water activity of dried Kishk could be used as monitoring procedure for the same aforementioned two steps.

\subsection{Corrective Actions}

Different corrective actions for each identified CCP were established. A corrective action for the receiving raw ingredients used in preparation Kishk was reject any doubtful ingredients as it not accompanied by supplier guarantee. Re-sieved cleaned grains are the corrective action should be taken for cleaning grain step if any physical hazards are seen visually. Check and repair incubation and drying conditions (temperature and time) and reprocess if necessary were the corrective actions could be established when monitoring procedures of incubation and drying steps had been indicated that, the critical limits of those steps were exceeded. 


\subsection{Verification Procedures}

The verification procedures for each identified CCP were established. Auditing of supplier guarantee and Visual inspection of characteristics for each ingredient were the verification procedures could be established for verifying receiving raw ingredients step. Test and visual inspection of sieves were the verification procedures for the step of cleaning grains during preparation Kishk. Regarding to incubation and drying steps, checked the conditions of incubation and drying steps (temperature and time) could be taken as verification procedures for verifying the aforementioned two CCPs. The incubation and drying steps were performed especially for controlling the safety of Kishk as $\mathrm{pH}$, acidity and water activity of the product were sufficient for controlling microbial growth especially pathogenic bacteria, spore forming bacteria, yeast and mold, [30]. So measuring the $\mathrm{pH}$, acidity and water activity of Kishk were the most verification procedures for verifying the incubation and drying steps during preparation Kishk as those steps related directly with the safety of Kishk, [31] [32] [33] [34]. As aforementioned reported $\mathrm{pH}$ values of different prepared Kishk samples were ranged from 4.39 to 4.84 , where values of acidity as \% lactic acid and water activity were ranged from 1.27 to 1.50 and 0.31 to 0.35 , respectively (Table 2 ). With respect to that, microbiological analysis of Kishk as end product was very important verification procedure could be established for verifying the HACCP plan during preparation of Kishk samples. Counts of total bacteria, lactic acid bacteria, coliform, yeast and mold for different Kishk samples were determined and the results were presented in Table 5. It could be noticed that, total bacterial counts of different Kishk samples were ranged from 5.15 to $7.50 \mathrm{log} \mathrm{cfu} / \mathrm{g}$, where lactic acid bacterial counts ranged from 6.04 to $7.88 \mathrm{log} \mathrm{cfu} / \mathrm{g}$. [35] determined the quality of Kishk made from a mixture of yoghurt and sago, the results showed that, total lactic acid bacteria was $6.32 \mathrm{log} \mathrm{cfu} / \mathrm{g}, 2.3 \%$ acidity, $\mathrm{pH}$ was 3.69 and $10.39 \%$ moisture content. From the same table it could be reported that, counts of coliform, yeast and mold was not detected at detection limit $<$ log cfu/g for any prepared Kishk samples. [34] prepared synbiotic Kishk from buffalo skim milk and crushed barley

Table 5. Microbiological analysis of different prepared Kishk samples.

\begin{tabular}{ccccc}
\hline \multirow{2}{*}{ Kishk samples } & \multicolumn{4}{c}{ Microbiological analysis (Log CFU/g) } \\
\cline { 2 - 5 } & Total bacterial count & Lactic acid bacteria & Coliform count & Yeast and molds \\
\hline CW1 & 7.30 & 7.88 & $\leq 1$ & $\leq 1$ \\
CW2 & 7.50 & 7.83 & $\leq 1$ & $\leq 1$ \\
CB & 6.08 & 6.80 & $\leq 1$ & $\leq 1$ \\
CM & 5.15 & 6.08 & $\leq 1$ & $\leq 1$ \\
GW1 & 7.25 & 7.80 & $\leq 1$ & $\leq 1$ \\
GW2 & 7.49 & 7.79 & $\leq 1$ & $\leq 1$ \\
GB & 5.90 & 6.79 & $\leq 1$ & $\leq 1$ \\
GM & 5.20 & 6.04 & $\leq 1$ & $\leq 1$ \\
\hline
\end{tabular}

$\leq 1$ : viable colony was not detected at detection limit $<\log \mathrm{CFU} / \mathrm{g}$. 
(2:1) and they found that preparation Kishk inhibited the growth of molds, yeasts and spore forming bacteria.

Finally it could be reported that, the low microbial load in the different prepared Kishk samples reflect the high sanitary conditions during the different preparing stages and no post-production contamination was occurring.

\subsection{Record Keeping Procedures}

Record keeping documents for each identified CCP during preparation Kishk samples were presented in Table 6. It could be observed that, keeping of supplier guarantee for each ingredient used in preparing Kishk and reports of visual inspection cleaned grains and testing sieves were the record documents for CCPs of receiving raw ingredients and cleaning grains, respectively. At the same time, reports of checking different conditions of incubation and Kishk dried were the documents should be keeping for these CCPs.

Finally it could be reported that, Table 3, Table 4, Table 6 and Figure 1 show formal documents that pulls together the keys information of HACCP plan for preparation of Kishk, and contain details of all that is critical to product safety. An important role of HACCP system is to help the food processor build safety preparation Kishk through identification of key or critical control measures that prevent, eliminate or reduce different hazards (biological, chemical and physical) to acceptable level as pre-

Table 6. HACCP worksheet for prepared Kishk samples.

\begin{tabular}{|c|c|c|c|c|c|c|}
\hline $\mathrm{CCP}$ & Hazard & Critical limits & Monitoring & Corrective actions & Verification & Record keeping \\
\hline $\begin{array}{l}\text { Receiving } \\
\text { wheat, barley } \\
\text { and millet } \\
\text { grains and cow } \\
\text { or goat yoghurt } \\
\text { and salt. }\end{array}$ & $\begin{array}{l}\text { Biological, } \\
\text { chemical } \\
\text { and } \\
\text { physical }\end{array}$ & $\begin{array}{l}\text { Supplier guarantees } \\
\text { specifications of } \\
\text { ingredients. }\end{array}$ & $\begin{array}{l}\text { Visual inspection of } \\
\text { supplier guarantee } \\
\text { and sensory } \\
\text { characteristics of } \\
\text { each ingredient. }\end{array}$ & $\begin{array}{l}\text { Reject any doubtful } \\
\text { ingredients. }\end{array}$ & $\begin{array}{l}\text { Auditing of supplier } \\
\text { guarantee and visual } \\
\text { inspection of } \\
\text { characteristics for } \\
\text { each ingredients. }\end{array}$ & Supplier guarantee \\
\hline $\begin{array}{l}\text { Cleaning of } \\
\text { grains. }\end{array}$ & Physical & $\begin{array}{l}\text { Sieved grains should not } \\
\text { contain physical hazards. }\end{array}$ & $\begin{array}{l}\text { Visual inspection of } \\
\text { cleaned grains. }\end{array}$ & $\begin{array}{l}\text { Grains should be } \\
\text { re-sieved if any } \\
\text { physical } \\
\text { contaminants are } \\
\text { seen visually. }\end{array}$ & $\begin{array}{l}\text { Test and visual } \\
\text { inspection of sieves. }\end{array}$ & $\begin{array}{l}\text { Reports of visual } \\
\text { inspection of cleaned } \\
\text { grains and testing of } \\
\text { sieves. }\end{array}$ \\
\hline $\begin{array}{l}\text { Incubation of } \\
\text { mixture. }\end{array}$ & Biological & $\begin{array}{l}\text { Compliance with general } \\
\text { recommendation of good } \\
\text { manufacturing practices. } \\
\text { Temperature of } \\
\text { incubation } 40^{\circ} \mathrm{C} \pm 2^{\circ} \mathrm{C} \\
\text { for } 24 \text { hrs. }\end{array}$ & $\begin{array}{l}\text { Checked of } \\
\text { temperature and } \\
\text { time of inculpation } \\
\text { and } \mathrm{pH} \text { of } \\
\text { cereals/yoghurt } \\
\text { mixture. }\end{array}$ & $\begin{array}{l}\text { Check and repair } \\
\text { incubation } \\
\text { conditions and } \\
\text { reprocess if } \\
\text { necessary (increase } \\
\text { time of incubation). }\end{array}$ & $\begin{array}{l}\text { Checked the } \\
\text { incubation conditions } \\
\text { and the final pH of } \\
\text { cereals/yoghurt } \\
\text { mixture. }\end{array}$ & $\begin{array}{l}\text { Reports of checked } \\
\text { temperature and time } \\
\text { of inculpation and } \mathrm{pH} \\
\text { of cereals/yoghurt } \\
\text { mixture. }\end{array}$ \\
\hline $\begin{array}{l}\text { Kishk formed } \\
\text { and dried. }\end{array}$ & Biological & $\begin{array}{l}\text { Compliance with general } \\
\text { recommendation of good } \\
\text { manufacturing practices. } \\
\text { Temperature of drying } \\
50^{\circ} \mathrm{C} \pm 2^{\circ} \mathrm{C} \text { for } 24 \mathrm{hrs} \text {. }\end{array}$ & $\begin{array}{l}\text { Checked } \\
\text { temperature and } \\
\text { time of drying } \\
\text { process and } \mathrm{pH}, \\
\text { acidity and water } \\
\text { activity of Kishk. }\end{array}$ & $\begin{array}{l}\text { Check and repair } \\
\text { drying conditions } \\
\text { and reprocess if } \\
\text { necessary (increase } \\
\text { time or temperature } \\
\text { of drying). }\end{array}$ & $\begin{array}{l}\text { Checked the drying } \\
\text { conditions and testing } \\
\text { the pH, water activity, } \\
\text { acidity and } \\
\text { microbiological load } \\
\text { of Kishk. }\end{array}$ & $\begin{array}{l}\text { Reports of checked the } \\
\text { drying conditions and } \\
\text { testing the } \mathrm{pH} \text {, water } \\
\text { activity, acidity and } \\
\text { microbiological load of } \\
\text { Kishk. }\end{array}$ \\
\hline
\end{tabular}


viously listed in Table 3 and Table 4. A HACCP worksheet contained the seven principles of HACCP system were presented in Table 6.

\section{Conclusion}

Kishk is known as fermented milk-wheat mixture; salted sour buttermilk and different types of cereals could be used in preparing the Kishk like barley and millet. Since Kishk is widely consumed, it is important to establish an affective food safety system as HACCP during preparation of Kishk for improving the safety and protection of the consumer. The results of our study showed that the use of good quality raw ingredients and controlling system was very important during production of Kishk. HACCP system is needed in order to improve the safety of prepared Kishk. HACCP system could evaluate the different sources of hazards during various preparation steps of Kishk and control its critical control points occurring by applying HACCP system.

\section{References}

[1] National Advisory Committee on Microbiological Criteria for Foods (NACMCF) (1998) Hazard Analysis Critical Control Point Principles and Application Guidelines. Journal of Food Protection, 61, 1246-1259.

[2] Sivasankar, B. (2002) Food Quality, in Food Processing and Preservation. Prentice-Hall of India Private Limited, New Delhi, 345.

[3] Gandhi, A.P. (2008) Development of HACCP Procedure for the Production of Full Fat Soy Flour. International Food Research Journal, 15, 141-154.

[4] Abd El-Malek, Y. and Demerdash, M. (1993) Egyptian Kishk. In: Steinkraus, K.H., Ed., Handbook of Indigenous Fermented Foods, Marcel Dekker, New York, 295-299.

[5] Tamime, A.Y., Barclay, M.N.I., O'connor, T.P. and Anifantakis, E.M. (1995) Comparison of Deferent Methods to Detect the Adulteration of Caprine Milk Kishk with Bovine Milk. In: Production and Utilization of Ewe and Goat Milk, International Dairy Federation, Brussels, Special Issue No. 9603, 214-217.

[6] Muir, D.D., Tamime, A.Y. and Hunter, E.A. (1995) Sensory Properties of Kishk: Comparison of Products Containing Bovine and Caprine Milk. International Journal of Dairy Technology, 48, 123-127. http://dx.doi.org/10.1111/j.1471-0307.1995.tb02481.x

[7] Tamime, A.Y., Barclay, M.N.I., Amarowiez, A. and McNulty, D. (1999a) Kishk-A Dried Fermented Milk/Cereal Mixture. 1. Composition of Gross Components, Carbohydrates, Organic Acids and Fatty Acids. Lait, 79, 317-330. http://dx.doi.org/10.1051/lait:1999327

[8] Tamime, A.Y. and O'connor, T.P. (1995) Kishk-A Dried Fermented Milk/Cereal Mixture. International Dairy Journal, 5, 109-128. http://dx.doi.org/10.1016/0958-6946(95)92205-I

[9] Tamime, A.Y., Barclay, M.I.A., Law, J.R., Leaver, J., Anifantakis, E.M. and O'connor, T.P. (1999b) Kishk-A Dried Fermented Milk/Cereal Mixture. 2. Assessment of a Variety of Protein Analytical Techniques for Determining Adulteration and Proteolysis. Lait, 79, 331339. http://dx.doi.org/10.1051/lait:1999328

[10] Attia, I.A. and Khattab, A.A. (1985) Microbiological and Chemical Studies on Kishk. Alexandria Exchange, 6, 63-71.

[11] Tamime, A.Y. and McNulty, D. (1999) Kishk-A Dried Fermented Milk/Cereal Mixture. 4. Microbiological Quality. Le Lait, 79, 449-456. http://dx.doi.org/10.1051/lait:1999437 
[12] Tamime, A.Y. and Robisons, R.K. (2007) Chapter 2: Background to Manufacturing Practice. In: Tamime, A.Y. and Robisons, R.K., Eds., Tamime and Robinsons Yoghurt. Science and Technology, 3rd Edition, Woodhead Publishing Ltd., Cambridge, 13-161. http://dx.doi.org/10.1533/9781845692612.13

[13] Tamime, A.Y., Muir, D.D., Barclay, M.N.I., Khaskheli, M. and Mcnulty, D. (1997) Laboratory-Made Kishk from Wheat, Oat and Barley: 2. Compositional Quality and Sensory Properties. Food Research International, 30, 319-326. http://dx.doi.org/10.1016/S0963-9969(97)00055-0

[14] Landrock, A.H. and Proctor, B.E. (1951) A New Graphic Interpolation Method for Obtaining Equilibrium Data with Special Reference to Its Role in Food Packaging Studies. Food Technology, 5, 332-336.

[15] Ling, E.R. (1963) Vol. 2: Practical. In: Ling, E.R., Ed., A Text Book of Dairy Chemistry, 3rd Edition, Chapman and Hall Ltd., London, 16-80.

[16] Adeleke, R.O. and Odedeji, J.O. (2010) Functional Properties of Wheat and Sweet Potato Flour Blends. Pakistan Journal of Nutrition, 9, 535-538.

http://dx.doi.org/10.3923/pjn.2010.535.538

[17] IDF (1992) Milk and Milk Products-Preparation of Samples and Dilutions for Microbiological Examination. Standard 122B, International Dairy Federation, Brussels.

[18] ADPI (1990) Standard for Guides of Dry Milks Including Methods of Analysis. Bulletin No. 916, American Dry Products Institute, Chicago.

[19] IDF (1991) Yogurt. Identification of Characteristic Micro-Organisms (Lactobacillus delbrueckii Subsp. Bulgaricus and Streptococcus salivarius Subsp. Thermophilus). Standard 146, International Dairy Federation, Brussels.

[20] IDF (1990) Milk and Milk Products 2 Enumeration of Yeasts and Moulds, Colony Count at 25 3C. Standard 94B, International Dairy Federation, Brussels.

[21] IDF (1985) Milk and Milk Products 2 Enumeration of Coliforms, Colony Count Technique and Most Probable Number Technique at 30 3C. Standard 73A, International Dairy Federation, Brussels.

[22] AOAC (2005) Official Methods of Analysis. 18th Edition, Association of Official Analytical Chemists, Washington DC.

[23] National Advisory Committee on Microbiological Criteria for Foods (NACMCF) (1992) Hazard Analysis Critical Control Point System. International Journal of Food Microbiolo$g y$, 16, 1-23. http://dx.doi.org/10.1016/0168-1605(92)90122-J

[24] Snedecor, G.W. and Cochran, W.G. (1980) Statistical Methods. 7th Edition, Iowa State University Press, Ames.

[25] Statistical Analysis System (SAS) (2000) SAS User's Guide. Version 8.1, SAS Institute Inc., Cary.

[26] Morcos, S.R. (1973) Egyptian Kishk. In: Steinkraus, K.H., Ed., Handbook of Indigenous Fermented Foods, Marcel Dekker, New York, 295-299.

[27] Damir, A.A., Salama, A.A. and Safwat M.M. (1992) Acidity, Microbial, Organic and Free Amino Acids Development during Fermentation of Skimmed Milk, Kishk. Food Chemistry, 43, 265-269. http://dx.doi.org/10.1016/0308-8146(92)90210-S

[28] Ismail, M.A. (1993) Degradative Enzymes and Fungal Flora Associated with the Egyptian Foodstuff Kishk. International Biodeterioration \& Biodegradation, 31, 143-157. http://dx.doi.org/10.1016/0964-8305(93)90070-I

[29] ISO 22000 (2005) Food Safety Management Systems Requirements for Any Organization the Food Chain. 
[30] Abou-Zeid, N.A. (2016) Review of Egyptian Cereal-Based Fermented Product (Kishk). International Journal of Agriculture Innovations and Research, 4, 600-609.

[31] Aloys, N. and Angeline, N. (2009) Traditional Fermented Foods and Beverages in Burundi. Food Research International, 42, 588-594. http://dx.doi.org/10.1016/j.foodres.2009.02.021

[32] Liu, S., Han, Y. and Zhou, Z. (2011) Lactic Acid Bacteria in Traditional Fermented Chinese Foods. Food Research International, 44, 643-651.

http://dx.doi.org/10.1016/j.foodres.2010.12.034

[33] El-Nawawy, M.A., Ibrahim, R., Al-Bonayan, A.M. and El-Beialy, A.R. (2012) Development of Functional Food Products. International Journal of Diary Science Research, 1, 12-17.

[34] Kebary, K.M.K., Kamaly, K.M., Abou-Zeid, N.A., Salem, O.M. and El-Den, E.A. (2014) Synbiotic Kishk as Functional Food. Menofia Journal of Agricultural Research, 39, 55-68.

[35] Nurliyani, I., Indratiningsih, I. and Rahmayanti, Y. (2013) Kualitas Kishk Yang Dibuat Dari Campuran Yogurt Dan Tepung Sagu (Metroxylon sp). Peran Teknologi dan Industri Pangan untuk Percepatan tercapainya Kedaulatan Pangan Indonesia, Jember, 26-29 Augustus 2013, 253-263.

Submit or recommend next manuscript to SCIRP and we will provide best service for you:

Accepting pre-submission inquiries through Email, Facebook, LinkedIn, Twitter, etc.

A wide selection of journals (inclusive of 9 subjects, more than 200 journals)

Providing 24-hour high-quality service

User-friendly online submission system

Fair and swift peer-review system

Efficient typesetting and proofreading procedure

Display of the result of downloads and visits, as well as the number of cited articles

Maximum dissemination of your research work

Submit your manuscript at: http://papersubmission.scirp.org/

Or contact fns@scirp.org 